\title{
EDITORIAL
}

\section{Energy Transition in a Transnational World}

\section{INTRODUCTION}

At the dawn of 2021 people worldwide looked for signs of hope: signs that the pandemic was waning; signs that politicians were prepared to act decisively on climate change; signs that pervasive patterns of social, political, and economic inequality could be exposed and dislodged. The New Year rang in optimism. Vaccines for COVID-19 began to roll out. ${ }^{1}$ President Joseph Biden assumed the United States (US) presidency, displacing Donald Trump and thereby removing a major impediment to transnational cooperation on health, the environment, and development. The youth climate movement continued to grow in power as voices for progressive, equity-oriented change rang out. ${ }^{2}$ Social, racial, and economic equality law reform movements swelled worldwide.

Even as 2021 offered fleeting rays of hope, it also ushered in devastating blows to the stability of political, economic, and social systems across the globe. On 6 January 2021 the US suffered one of the greatest contemporary threats to its democracy when insurgents stormed the Capitol. ${ }^{3}$ Humanitarian and refugee crises deepened in Yemen, Venezuela, Myanmar, and along the southern border of the US. ${ }^{4}$ Catastrophic rains and floods inundated New South Wales (Australia), ${ }^{5}$ and devastating fires swept across Cape Town (South Africa), ${ }^{6}$ while President Jair Bolsonaro sought to leverage the future of the Amazon rainforest. ${ }^{7}$ Meanwhile, as the large, wealthy countries refined

1 See K. Collins \& J. Holder, 'See How Rich Countries Got to the Front of the Vaccine Lines', New York Times, 31 Mar. 2021, available at: https://www.nytimes.com/interactive/2021/03/31/world/global-vaccine-supply-inequity.html.

2 See L. Pike, 'Youth Climate Activists Are Back with New, Sharper Demands for Countries and Corporations', Vox, 29 Mar. 2021, available at: https://www.vox.com/2021/3/20/22340607/climatechange-strike-greta-thunberg-fridays-for-future-net-zero-emissions.

3 See L. Diamond, 'The Capitol Siege Is the Wake-up Call America Shouldn't Have Needed', Foreign Affairs, 7 Jan. 2021, available at: https://www.foreignaffairs.com/articles/united-states/2021-01-07/capitol-siege-wake-call-america-shouldnt-have-needed.

4 See United Nations (UN) Human Rights Council, 'Emergencies', available at: https://www.unrefugees. org/emergencies.

5 NASA Earth Observatory, 'Historic Floods in New South Wales', Mar. 2021, available at: https://earthobservatory.nasa.gov/images/148093/historic-floods-in-new-south-wales.

6 J.J. Diaz, 'Fast Moving Fire on Table Mountain Destroys South African Landmarks, History', NPR News, 19 Apr. 2021), available at: https://www.npr.org/2021/04/19/988640656/fast-moving-fire-ontable-mountain-destroys-south-african-landmarks-history.

7 B. Harris, 'Brazil Seeks 1bn Cash Upfront for Preservation of Amazon', Financial Times, 14 Apr. 2021, available at: https://www.ft.com/content/b8dfe545-0869-4de0-8ba6-1c7715c191cd. 
their COVID-19 vaccine rollouts, rates of infections skyrocketed in Brazil and India to devastating effect and vaccine availability in many countries in the global south remains shockingly low. ${ }^{8}$ Moreover, as the world slowly and unsteadily emerges from varying levels of lockdown, global carbon emissions begin to rise quickly. ${ }^{9}$

The dizzying highs and lows of the first few months of 2021 revealed the contours of a world grappling with multiple overlapping crises as the pandemic continued to intersect with the global ecological crisis and a persistent crisis of world order. ${ }^{10}$ To put it bluntly, the global order is under pressure. On one side, the growth of right-wing populist $^{11}$ and nationalist sentiment ${ }^{12}$ as well as the persistence of authoritarian regimes create downward pressure on international and transnational law, international order, and on the notion that we are a global community and can cooperate as such. ${ }^{13}$ On the other, a growing group of scholars and advocates, including TWAIL (Third World Approaches to International Law) scholars, ${ }^{14}$ are raising their collective voice to question the legitimacy of the post-World War II liberal order - including the core structures and institutions of international and transnational law - and the degree to which this liberal order really is (or ever was) accepted by wide swaths of the global population. These voices challenge the degree to which existing systems of law reflect consensus and shared values. The pandemic, demands for radical social reform, and the deepening global ecological crisis overlay and compound these pressures on governance systems and the rule of law. ${ }^{15}$ The intersecting crises, however, also are propelling social movements and law reform projects ${ }^{16}$ that embrace more inclusive visions of life under and beyond the rule of law and reveal how crisis can function as a catalyst for re-imagining law as a tool for change.

8 See S. Hegarty, 'Covid Vaccine Tracker: How's My Country and the Rest of the World Doing?', BBC News, 12 Feb. 2021, available at: https://www.bbc.com/news/world-56025355.

9 'Greenhouse Gas Emissions Are Set to Rise Fast in 2021', The Economist, 20 Apr. 2021, available at: https://www.economist.com/graphic-detail/2021/04/20/greenhouse-gas-emissions-are-set-to-rise-fast-in2021.

10 See C. Carlarne, 'Climate Change, Human Rights, \& The Rule of Law: Untangling the Rights-Rule of Law Relationship in the Climate Change Context' (2020) 25(1) UCLA Journal of International Law \& Foreign Affairs, pp. 11-40; M. Helal, 'The Crisis of the World Order and the Constitutive Regime of the International System' (2019) 46(3) Florida State University Law Review, pp. 569-640.

11 See N. Lacey, 'Populism and the Rule of Law', London School of Economics and Political Science, Working Paper No. 28, 2019, available at: http://eprints.lse.ac.uk/101867/1/ Lacey_populism_and_the_rule_of_law_wp28.pdf.

12 See UN Security Council, Press Release, 'Rising Nationalism Threatens Multilateralism's 70-Year "Proven Track Record" of Saving Lives, Preventing Wars, Secretary-General Tells Security Council', UN Press Release SC/13570, 9 Nov. 2018.

13 E.g., C.P. Carlarne \& M.S. Helal, 'A Conversation about Climate Change Law and the 'International Community' (2018) 8(22) Climate Law, pp. 229-43.

14 See M.W. Mutua, 'What is TWAIL?' (2000) 94(1) Proceedings of the Annual Meeting of the American Society of International Law, pp. 31-40; J.T. Gathii, 'Rejoinder: Twailing International Law' (2000) 98(6) Michigan Law Review, pp. 2066-7.

15 See P. Sands, 'Climate Change and the Rule of Law: Adjudicating the Future in International Law' (2016) 28(1) Journal of Environmental Law, pp. 19-35, at 32.

16 E.g., A. Akbar, S. Ashar \& J. Simonson, 'Movement Law' (2021) 73(4) Stanford Law Review, pp. 82184; A. Akbar, 'Demands for a Democratic Political Economy' (2020) 134(1) Harvard Law Review Forum, pp. 90-118. 
Within the sphere of environmental law, the climate crisis is increasingly understood to be an intersectional challenge that implicates and exacerbates existing systemic challenges and prevailing pathways of inequality. From this vantage point climate change also creates opportunities for rethinking the role of law in limiting the destructive impacts of climate change and moving towards a more sustainable and equitable world in the process. This view is advanced by the climate justice movement, which is swelling in influence worldwide. Drawing from the environmental justice movement, ${ }^{17}$ the climate justice movement exposes not only how social and economic inequality has led to and perpetuates patterns of climate change, but also how climate change deepens inequality by disproportionately affecting the most vulnerable members of society. Climate justice seeks greater emphasis on this issue and advocates on the part of those most affected by climate change. The movement envisions a world which simultaneously curtails the negative effects of climate change and reshapes existing social, political, and economic relationships along the way.

Amidst the overlapping crises of modern times, the modern climate justice movement is reviving dialogue at the intersection of feminism, environmentalism, social and economic justice, and other progressive law reform movements, as well as creating the space and momentum for intersectional ideas to flourish. For lawyers and legal scholars, the opportunity is to see climate change and environmental degradation within its broader social context and to seize upon the rule of law as a powerful tool for change.

Nowhere are these intersecting challenges as acute as in the context of energy. One of the principal aims of the climate justice movement is to achieve a just and equitable transition from an extractive economy to a regenerative economy. This requires transitioning from fossil fuel-dependent to low and zero-carbon economies. ${ }^{18}$ However, the pathways for overhauling energy systems worldwide remain indeterminate. Energy systems are evolving in response to a combination of law and policy changes, developments in energy technologies, and market forces. Moreover, given both the entrenched nature of fossil fuel economies and the varied social, political, economic, and environmental factors that shape energy transition, pathways to decarbonization are bound to be beset with complex trade-offs, such as those between energy security and environmental objectives, or between energy choice and economies of scale. The precise contours of these systemic changes vary from country to country, and remain under-explored both within their national contexts and from a broader transnational perspective. This knowledge gap is critical. Understanding how, why, and to what end states are restructuring their energy economies is essential for transitioning to more environmentally sustainable and just societies worldwide. In short, this is an area in need of experimentation and iterative learning. It is a subject ripe for greater

17 E.g., R.R. Kuehn, 'A Taxonomy of Environmental Justice' (2000) 30(10) Environmental Law Reporter News \& Analysis, pp. 10693-4; G. Torres, 'Introduction: Understanding Environmental Racism' (1992) 63(4) University of Colorado Law Review, pp. 839-48.

18 E.g., S. Welton \& J. Eisen, 'Clean Energy Justice: Charting an Emerging Agenda' (2019) 43(2) Harvard Environmental Law Review, pp. 307-71; A.M. Eisenberg, 'Just Transitions' (2019) 92(2) Southern California Law Review, pp. 273-330. 
scholarly focus, particularly at the transnational level, where improved learning and sharing is indispensable for achieving the global-level shifts needed to address climate change.

Transnational Environmental Law (TEL) is particularly well suited to advance scholarly inquiry at the frontier of energy transition. Since its inception TEL has helped to identify the grey areas between national and international legal development, and to explore the rapidly expanding body of law that fills and pushes at the edges of these interstitial spaces. Along the way, the field of transnational environmental law has matured even as the challenges it seeks to address have deepened and widened. Energy transition is one such challenge, and it demands careful comparative and transnational analysis. That is precisely what this issue of TEL sets out to deliver.

\section{ENERGY SYSTEMS IN TRANSITION}

This issue of TEL highlights the importance of energy transition and brings transnational and comparative lenses to bear in this rapidly evolving context. It does so through an extensive Symposium collection exploring the law of energy transition in federal systems, ${ }^{19}$ before turning to a case comment that examines how, in a preliminary ruling, the Court of Justice of the European Union (CJEU) responded to potential conflicts between environmental objectives and national energy security. ${ }^{20}$ Together, these pieces offer rich insight into the complex terrain of energy transition.

The Symposium collection speaks directly to this need. The articles in the Symposium emerge from a June 2019 workshop hosted by the Eberhard Karls University of Tübingen (Germany) and the University of North Carolina School of Law (US), entitled 'The Law of Energy Transition in Federal Systems'. The focus of the workshop and the resulting Symposium articles is on exploring how federalist legal systems affect energy transitions in specific countries such as Australia, South Africa, Switzerland, Germany, the US, and in the legal order of the European Union (EU), as well as offering comparative analyses of how differing systems of federalism influence modes of energy transition.

Through a collection of six articles introduced in a Symposium Foreword by the conveners, Johannes Saurer and Jonas Monast, the Symposium offers novel insight into the ways in which different federalist legal frameworks might advance or impede the transition to cleaner energy systems. The articles deepen the conversation around energy transition and offer detailed accounts of the federalist legal structures in states as varied as Australia, South Africa, and the US, and then layer these accounts with details about how energy law has emerged and evolved within these distinct frameworks. This includes an accounting not just of the 'allocation of lawmaking authority among

19 J. Saurer \& J. Monast, 'The Law of Energy Transition in Federal Systems' (2021) 10(2) Transnational Environmental Law, pp. 205-10.

20 I. Cenevska, 'Environmental Protection Meets Security of Electricity Supply: Case C-411/17, Inter-Environnement Wallonie ASBL and Bond Beter Leefmilien Vlaanderen ASBL v. Conseil des ministres, Court of Justice of the European Union' (2021) 10(2) Transnational Environmental Law, pp. 365-82. 
federal and sub-federal actors', but also of the essential role that 'economic circumstances, political ideologies, and energy resources' play in shaping energy law and policy choices. ${ }^{21}$ Notably, structural and historical accounts of federalism and energy law are themselves important contributions to the emerging scholarship on energy federalism. For the Symposium articles, however, these accounts serve as scaffolding for further inquiry into the ways in which federalist legal structures influence energy transition in complex and, often, surprising ways. Each article offers a careful and, at times, comparative, ${ }^{22}$ analysis of how the federalist systems are and may constrain choice, 'create conflicting goals', and 'hinder the pursuit of a clear course in energy policy'. ${ }^{23}$ Equally, the articles offer insight into how energy federalism offers opportunities for sub-federal entities 'to experiment with energy policies that reflect their respective resources and goals', and to develop decentralized energy policies that may be 'more resilient to sudden policy shifts at the federal level'. ${ }^{24}$

Across federalist systems, the articles offer deeply varied accounts of the ways in which they operate, and both the observed and predicted ways in which these multilayer governance systems will interact with efforts to decarbonize energy systems. To be sure, general themes emerge. The balance of power and authority between state and federal authorities over energy matters is often still in flux, but is always consequential. Conflicts are emerging more frequently as energy transitions advance. There is an urgent need for greater competencies at different levels of government and improved mechanisms for coordination. ${ }^{25}$ Above all, perhaps, as supranational, national, and subnational actors work to determine roles and responsibilities, there is an urgent need to maintain scope for experimentation and innovation. ${ }^{26}$

Complementing the Symposium articles is a contribution by Ilina Cenevska. ${ }^{27}$ In this case comment, Cenevska discusses Inter-Environnement Wallonie ASBL and Bond Beter Leefmilieu Vlaanderen ASBL v. Conseil des ministres, ${ }^{28}$ in which the Belgian Constitutional Court (BCC) sought a preliminary ruling from the CJEU in response to proceedings raised by two Belgian environmental protection organizations. These organizations challenged a 2015 Belgian law that extended the operation of two nuclear power stations by ten years, delaying the year by which they were due to be closed from 2015 until 2025. ${ }^{29}$ At issue in the case was the relationship between

21 Saurer \& Monast, n. 19 above, p. 206.

22 E.g., F. Mormann, 'Of Markets and Subsidies: Counter-intuitive Trends for Clean Energy Policy in the European Union and the United States' (2021) 10(2) Transnational Environmental Law, pp. 321-37; J. Saurer \& J. Monast, 'Renewable Energy Federalism in Germany and the United States' (2021) 10(2) Transnational Environmental Law, pp. 293-320.

Saurer \& Monast, n. 19 above, p. 207.

Saurer \& Monast, n. 22 above, p. 320.

Saurer \& Monast, n. 19, p. 210.

26

Fehling, 'Energy Transition in the European Union and its Member States: Interpreting Federal Competence Allocation in the Light of the Paris Agreement' (2021) 10(2) Transnational Environmental Law, pp. 339-63, at 363.

27 Cenevska, n. 20 above.

28 Case C-411/17, ECLI:EU:C:2019:622.

29 Loi du 28 juin 2015 modifiant la loi du 31 janvier 2003 sur la sortie progressive de l'énergie nucléaire à des fins de production industrielle d'électricité afin de garantir la sécurité d'approvisionnement sur le plan 
achieving core EU environmental objectives and ensuring the security of Belgium's electricity supply. As Cenevska describes, the environmental associations argued that the 2015 law 'breached the requirements for a prior impact assessment under relevant international conventions to which the EU is a party, as well as relevant EU legislation', including environmental obligations arising from the Espoo Convention, ${ }^{30}$ the Aarhus Convention, ${ }^{31}$ and the EU's Birds Directive, ${ }^{32}$ Habitats Directive, ${ }^{33}$ and Environmental Impact Assessment Directive. ${ }^{34}$

Cenevska's case comment engages a similar set of questions to those that inform the Symposium collection, namely, what are the legal and structural barriers to transitioning to clean energy and how will legal systems respond when confronted with potential conflicts between competing policy objectives? In this case of first impression, the CJEU was challenged to navigate the relationship between environmental objectives and energy security. Also, reflecting the challenges raised in the Symposium articles, the Court had to consider the delicate balance of power between the EU and its Member States. Cenevska's meticulous analysis of the Court's reasoning in this case demonstrates both the very real tensions that exist between environmental, security, and economic objectives and the ways in which these tensions implicate precise and seemingly intractable questions of law, as well as much broader questions involving power, sovereignty, and disparate visions for the role of the rule of law in achieving decarbonization.

As Cenevska discusses, both the CJEU and, ultimately, the BCC strike what amounts to a substantive and procedural compromise. Although the CJEU found that the 2015 Belgian law breached EU environmental obligations, it 'exceptionally allowed the national court to suspend the effects of the ruling and maintain the effects of the Belgian measures', a decision it found to be 'justified in the light of the overriding considerations relating to the need to nullify a genuine and serious threat of rupture of the electricity supply in the Member State, one that cannot be remedied by any other means or alternative'. With this decision the CJEU acknowledged the breach of environmental obligations while sustaining Belgium's ability to maintain its current energy security policy, thereby skilfully evading the need to address the substantive tension between

énergétique [Law of 28 June 2015 amending the Law of 31 January 2003 on the Phasing Out of Nuclear Energy for the Purposes of the Industrial Production of Electricity in order to Ensure Security of the Energy Supply], Moniteur belge of 6 July 2015, p. 44423.

30 United Nations Economic Commission for Europe (UNECE) Convention on Environmental Impact Assessment in a Transboundary Context (Espoo Convention), Espoo (Finland), 25 Feb, 1991, in force 10 Sept. 1997, available at: https:/unece.org/fileadmin/DAM/env/eia/eia.htm.

31 UNECE Convention on Access to Information, Public Participation in Decision-making and Access to Justice in Environmental Matters (Aarhus Convention), Aarhus (Denmark), 25 June 1998, in force 30 Oct. 2001, available at: http://www.unece.org/env/pp/treatytext.html.

32 Directive 2009/147/EC on the Conservation of Wild Birds [2010] OJ L 20/7 (as amended by Directive 2013/17/EU [2013] OJ L 158/193).

33 Directive 92/43/EEC on the Conservation of Natural Habitats and of Wild Fauna and Flora [1992] OJ L 206/7 (as amended by Directive 2013/17/EU [2013] OJ L 158/193).

34 Directive 2011/92/EU on the Assessment of the Effects of Certain Public and Private Projects on the Environment [2012] OJ L 26/1; Cenevska, n. 20 above, p. 369.

35 Cenevska, n. 20 above, p. 379. 
energy security and environmental protection. Moreover, in doing so, the CJEU emphasized the breadth of discretion it afforded to Member States to invoke and interpret the energy security exemption in the context of environmental policy. ${ }^{36}$ The BCC, likewise, carefully threaded the needle and annulled the 2015 law while maintaining the effects of the law (allowing the nuclear plans to remain open) until such time as is necessary to remedy the environmental breaches on grounds that doing so was necessary to protect the security of the Belgian electricity supply. ${ }^{37}$

Cenevska offers a meticulous analysis of the ways in which policy objectives are likely to collide on the pathway to energy transition. Given that this case may foreshadow similar disputes in the future, Cenevska's case comment provides critical insight into how the CJEU is likely to navigate complex procedural and substantive questions at the intersection of energy, the environment, and Member State relations. Perhaps foreshadowing what is to come, even as the CJEU attempted to find a 'win-win scenario for both the objective of ensuring security of electricity supply and the environmental protection objective', in the end electricity supply won " a little bit more", 38

Together, the Symposium articles and Cenevska's case comment illustrate the challenges that energy transition poses to federalist and non-federalist systems alike. As states worldwide move to diversify and decarbonize their energy systems, profound legal and policy challenges will arise. Trade-offs between core policy goals will be required. These pieces offer valuable insight into how federalist systems variously constrain and enable the transition of energy sectors and create a roadmap for future scholarly inquiry.

\section{CONCLUSION}

In 2021 the world remains besieged by social, political, human health, and environmental crises. In a sign of the disorienting times, as people celebrated the $51^{\text {st }}$ Earth Day on 22 April 2021, British Prime Minister Boris Johnson offered a bewildering call for action on climate change. In advocating progress on climate change, he maintained that tackling climate change is about 'growth and jobs', not about 'some expensive, politically correct, green act of bunny hugging'. ${ }^{39}$ As absurd as the statement was, it revealed a deep-seeded and still prevalent perception that environmental issues and, by extension, environmental law remain the domain of fringe activists campaigning for simplistic or impractical objectives. The reality, of course, is that environmental law - in its domestic, transnational, and international iterations - provides important and

36 Ibid., p. 373.

37 Ibid., p. 380 (discussing the decision of the Constitutional Court of Belgium (Cour constitutionnelle): Arrêt n' 34/2020 du 5 mars 2020 en cause: Le recours en annulation de la loi du 28 juin 2015 'modifiant la loi du 31 janvier 2003 sur la sortie progressive de l'énergie nucléaire à des fins de production industrielle d'électricité afin de garantir la sécurité d'approvisionnement sur le plan énergétique', introduit par l'ASBL 'Inter-Environnement Wallonie' et l'ASBL 'Bond Beter Leefmilieu Vlaanderen', available at: https://www.const-court.be/public/f/2020/2020-034f.pdf (in French)).

38 Cenevska, n. 20 above, p. 382.

39 'Boris Johnson: Climate Change about Jobs not "Bunny Hugging"', BBC News, 23 Apr. 2021, available at: https://www.bbc.com/news/uk-politics-56843367. 
sophisticated tools for confronting some of the greatest challenges of our time. Finding ways to leverage and deepen environmental law is essential to advance environmental objectives and, ultimately, to find ways to build a safer and more just world for all. ${ }^{40}$ To this end, the articles and case comment in this issue engage one of the greatest environmental and equity challenges of our time: energy transition. In doing so, they contribute to a desperately needed understanding of how to leverage the rule of law as a tool for positive change.

Editors-in-Chief

Thijs Etty

Veerle Heyvaert

Editors

Cinnamon Carlarne

Bruce Huber

Jacqueline Peel

Josephine van Zeben

40 See N.S. Diffenbaugh \& M. Burke, ‘Global Warming Has Increased Global Inequality’ (2019) 116(20) PNAS, 9808-13, at 9808, available at: https://www.pnas.org/content/116/20/9808. 